\title{
Correction to: Associations between I/D polymorphism in the ACE gene and lung cancer: an updated systematic review and a meta-analysis
}

\author{
Junjian Chen, Mao Sun, Min Zhou and Renfu Lu*
}

\section{Correction to: BMC Cancer 21, 158 (2021) \\ https://doi.org/10.1186/s12885-021-07825-5}

Following publication of the original article [1], the authors reported an error in their affiliation.

The corrected affiliation is: Department of Cardiothoracic Surgery, Chongqing Emergency Medical Center, Chongqing University Center Hospital, School of Medicine, Chongqing University, No.1 Healthy Road, Yuzhong District, Chongqing, 400014 China

The original article [1] has been corrected.

Published online: 25 February 2021

\section{Reference}

1. Chen J, Sun M, Zhou M, et al. Associations between I/D polymorphism in the ACE gene and lung cancer: an updated systematic review and a meta-analysis. BMC Cancer. 2021;21:158 https://doi.org/10.1186/s12885021-07825-5.

\footnotetext{
The original article can be found online at https://doi.org/10.1186/s12885021-07825-5.

* Correspondence: lurenfu2007@163.com

Department of Cardiothoracic Surgery, Chongqing Emergency Medical

Center, Chongqing University Center Hospital, School of Medicine,

Chongqing University, No.1 Healthy Road, Yuzhong District, Chongqing

400014, China
}

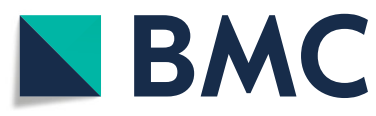

(c) The Author(s). 2021 Open Access This article is licensed under a Creative Commons Attribution 4.0 International License, which permits use, sharing, adaptation, distribution and reproduction in any medium or format, as long as you give appropriate credit to the original author(s) and the source, provide a link to the Creative Commons licence, and indicate if changes were made. The images or other third party material in this article are included in the article's Creative Commons licence, unless indicated otherwise in a credit line to the material. If material is not included in the article's Creative Commons licence and your intended use is not permitted by statutory regulation or exceeds the permitted use, you will need to obtain permission directly from the copyright holder. To view a copy of this licence, visit http://creativecommons.org/licenses/by/4.0/ The Creative Commons Public Domain Dedication waiver (http://creativecommons.org/publicdomain/zero/1.0/) applies to the data made available in this article, unless otherwise stated in a credit line to the data. 